\title{
Pengaruh TATO, DER dan Current Ratio terhadap ROA pda Perusahaan Property dan Real Estate
}

\author{
Trisha Wanny \\ Universitas Prima \\ Indonesia \\ Medan, Indonesia \\ trishawanny@gmail.com \\ Merrisa \\ Universitas Prima \\ Indonesia \\ Medan, Indonesia \\ 12merrisaxie@gmail.com
}

\author{
Jenni \\ Universitas Prima \\ Indonesia \\ Medan, Indonesia \\ Jtanzil75@gmail.com \\ Erlin \\ Universitas Prima \\ Indonesia \\ Medan, Indonesia \\ Erlinphen97@gmail.com
}

\author{
Lau Yeni \\ Universitas Prima \\ Indonesia \\ Medan, Indonesia \\ Lauyeni940@gmail.com \\ Isna Asdiani Nasution \\ Universitas Prima \\ Indonesia Medan, \\ Indonesia \\ Isnanasution@gmail.com
}

\begin{abstract}
ABSTRAK
Penelitian ini dilakukan pada perusahaan property dan real estate yang tercatat di Bursa Efek Indonesia. Penelitian ini bertujuan untuk menguji dan menganalisis pengaruh total asset turnover, debt to equity ratio dan current ratio terhadap return on asset. Metode penelitian yang digunakan dalam penelitian ini menggunakan metode pendekatan deduktif, jenis penelitian adalah kuantitatif yang bersifat deskriptif. Jumlah populasi dalam penelitian ini berjumlah 49 perusahaan dengan menggunakan teknik purposive sampling sehingga sampel menjadi 31 perusahaan. Metode analisis yang digunakan dalam penelitian ini adalah metode regresi linier berganda dan uji asumsi klasik. Hasil penelitian ini menunjukkan secara simultan Total Asset Turn Over, Debt to Equity Ratio dan Current Ratio berpengaruh terhadap ROA pada perusahaan Property dan real estate yang terdaftar di Bursa Efek Indonesia periode 2014-2017, dengan hasil $F_{\text {hitung }}=37,488>F_{\text {tabel }}=2,68$ dan signifikan $0,000<$ 0,05 . Secara parsial 1) TATO berpengaruh positif signifikan terhadap ROA, 2) DER berpengaruh negative dan signifikan terhadap ROA dan 3) CR tidak berpengaruh terhadap ROA. Hasil analisis koefisien determinasi diperoleh nilai Adjusted $\mathrm{R}^{2}$ sebesar 0,471 yang artinya variasi variabel ROA yang dapat dijelaskan oleh variasi variabel TATO, DER dan CR adalah sebesar 47,1\% sedangkan sisanya sebesar $52,9 \%$ dijelaskan oleh variabel bebas lainnya.
\end{abstract}

Kata Kunci : Total Asset Turn Over, Debt to Equity Ratio, Current Ratio dan Return on Asset

\section{ABSTRACT}

This research was conducted on property and real estate companies listed on the Indonesia Stock Exchange. This study aims to examine and analyze the effect of total asset turnover, debt to equity ratio and current ratio to return on assets. The research method used in this study uses the deductive approach, the type of research is quantitative descriptive. The total population in this study amounted to 49 companies using purposive sampling technique so that the sample became 31 companies. The analytical method used in this study is multiple linear regression methods and classical assumption tests. The results of this study show simultaneously Total Asset Turn Over, Debt to Equity Ratio and Current Ratio affect ROA on Property and real estate companies listed on the Indonesia Stock Exchange for the period 2014-2017, with the results of Fcount = 37,488> Ftable $=2.68$ and significant $0,000<0,05$. Partially 1) TATO has a significant positive effect on 
ROA, 2) DER has a negative and significant effect on ROA and 3) CR does not affect ROA. The results of the analysis of the determination coefficient obtained the adjusted $R 2$ value of 0.471 , which means that the variable variation of ROA which can be explained by variations in the variables TATO, DER and CR is equal to $47.1 \%$ while the remaining $52.9 \%$ is explained by other independent variables.

Keywords :Total Asset Turn Over, Debt to Equity Ratio, Current Ratio and Return on Asset

\section{PENDAHULUAN}

\subsection{Latar Belakang}

Bursa Efek Indonesia telah menjadi bagian penting dari berkembangnya perekonomian Indonesia. Bursa Efek Indonesia sebagai salah satu pasar modalyang dapat dijadikan alternatif pendanaan bagi semua sektor perusahaan di Indonesia. Salah satu alternatif pendanaan adalah melalui penerbitan dan penjualan saham di Pasar Modal atau Bursa Efek. Dalam pasar modal memungkinkan investor membuat pilihan atas investasi yang diinginkan sesuai dengan risiko dan tingkat keuntungan yang diharapkan.

Laporan keuangan dapat dijadikan sebagai acuan dalam rangka menilai kinerja perusahaan melalui efisiensi dari aktivitas dalam menghasilkan keuntungan. Apabila suatu informasi disajikan dengan benar, informasi tersebut sangat berguna bagi perusahaan dalam pengambilan keputusan dan untuk mengetahui kinerja perusahaan. Untuk mengukur seberapa besar keberhasilan perusahaan dalam memperoleh tingkat pengembalian atas laba maka perlu dilakukan analisis keuangan dengan rasio Profitabilitas.

Rasio profitabilitas adalah kemampuan perusahaan menghasilkan laba pada suatu periode tertentu. Pada penelitian ini menggunakan Return On Asset(ROA) yang diukur berdasarkan perbandingan antara laba bersih setelah pajak dengan total aktiva perusahaan. Semakin tinggi perbandingan laba bersih terhadap total aktiva maka akan semakin baik bagi perusahaan berarti perusahaan telah memanfaatkan aktiva yang ada dengan baik untuk menghasilkan keuntungan. Semakin tinggi Return On Asset suatu perusahaan maka dapat dikatakan profitabilitas perusahaan tersebut semakin bagus. Sebaliknya, jika menurun maka profitabilitas perusahaan tersebut juga menurun. Profitabilitas disini adalah kemampuan perusahaan untuk menghasilkan laba yang semakin tinggi rasio tersebut diperusahaan maka akan dipandang baik untuk para investor menanamkan modalnya diperusahaan tersebut. Ada beberapa faktor yang mempengaruhi rentabilitas antara lain total asset turnover, debt to equity ratio dan current ratio.

Total Assets Turnover merupakan perbandingan antara penjualan bersih dengan total aktiva dalam perusahaan. Jadi semakin besar rasio ini maka semakin baik berarti bahwa aktiva dapat lebih cepat berputar dan meraih laba, sehingga menunjukkan semakin efisien penggunaan keseluruhan aktiva dalam menghasilkan penjualanatau jumlah aset yang sama dapat memperbesar volume penjualan apabila Total Assets Turnover ditingkatkan atau diperbesar.

Rasio leverage adalah rasio yang digunakan untuk mengukur seberapa besar aktiva yang dimiliki perusahaan berasal dari hutang atau modal, sehingga dengan rasio ini dapat diketahui posisi perusahaan dan kewajibannya yang bersifat tetap kepada pihak lain serta keseimbangan nilai aktiva tetap dengan modal yang ada. Penggunaan hutang mengakibatkan peningkatan porsi laba perusahaan yang semakin tinggi nilai dan harga sahamnya. Semakin meningkat 
penggunaan hutang (debt to equity ratio) maka ketika kondisi ekonomi semakin memburuk misalnya penjualan semakin menurun maka akan menyebabkan penurunan pada return on asset.

Rasio Likuiditas ialah aktiva yang diperdagangkan dalam suatu pasar yang aktif sehingga akibatnya dapat dengan cepat diubah menjadi kas likuiditas sangat penting bagi perusahaan, jika berada dalam keadaan likuid, maka kesempatan untuk memperoleh laba yang besar. Jika tidak dalam keadaan likuid, maka untuk memperoleh laba pada perusahaan tersebut terbatas. Semakin meningkat current ratio menunjukkan perusahaan dalam keadaan likuid sehingga dapat menyebabkan peningkatan pada return on asset.

Penelitian terdahulu juga menunjukkan adanya pengaruh positif signifikan secara parsial Current Ratio dan Debt to Equity Ratio terhadap return on asset oleh Mahardhika dan Marbun (2016) dan peneliti lainnya Pranata, dkk (2014) juga membuktikan adanya pengaruh positif signifikan Total Aset Turnover terhadap ROA.

Berdasarkan uraian diatas, maka peneliti tertarik untuk melakukan penelitian dengan judul "PengaruhTotal Asset Turnover, Debt to Equity Ratiodan Current Ratio Terhadap Return On AssetPada Perusahaan Property dan Real Estate yang Tercatatdi Bursa Efek Indonesia Periode 2014-2017".

\subsection{Tujuan Penelitian}

Adapun yang yang menjadi tujuan penelitian ini adalah :

1. Untuk menguji dan menganalisis pengaruh total asset turnover, debt to equity ratio dan current ratio secara parsial terhadap return on asset pada perusahaan property dan real estate yang tercatatdi Bursa Efek Indonesia periode 2014-2017.
2. Untuk menguji dan menganalisis pengaruh total asset turnover, debt to equity ratio dan current ratio secara simultan terhadap return on asset pada perusahaan property dan real estate yang tercatat di Bursa Efek Indonesia periode 2014-2017

\subsection{Permasalahan}

Adapun permasalahan dalam penelitian ini adalah :

1. Kenaikan total asset turnover dan current ratio tidak selalu diikuti dengan kenaikan return on asset pada perusahaan property dan real estate yang tercatat di Bursa Efek Indonesia periode 2014-2017.

2. Kenaikan debt to equity ratio tidak selalu diikuti dengan penurunan return on asset pada perusahaan property dan real estate yang tercatat di Bursa Efek Indonesia periode 2014-2017.

\section{Kajian Pustaka}

\subsection{Total Assets Turn Over}

Menurut Syaifullah (2014:177) "Total

Asset Turnover menunjukkan kemampuan manajemen mengelola seluruh investasi (aktiva) guna menghasilkan penjualan."

Menurut Sinaga (2014:242),"semakin besar rasio ini semakin baik karena perusahaan tersebut dianggap efektif dalam mengelola asetnya." Menurut $\begin{array}{r}\text { Sartono } \\ \text { aktiva, }\end{array}$ menunjukkan
perputaran total $\begin{array}{r}\text { perusahaan } \\ \text { bagaimana efektivitas }\end{array}$
menggunakan keseluruhan aktiva untuk
menciptakan penjualan dan mendapatkan laba.

\subsection{Debt to Equity Ratio}

Menurut Sugiono dan Untung (2016:60), rasio DER merupakan salah satu rasio yang penting karena berkaitan dengan masalah trading on equity yang dapat memberikan pengaruh positif maupun negative terhadap 
rentabilitas modal sendiri dari perusahaan tersebut.

Menurut Jusuf (2014:60-61), secara umum dapat dikatakan bahwa semakin tinggi rasio ini, semakin besar risiko kreditor (termasuk bank). DER lebih besar dari 1 (satu) menunjukkan bahwa sumber pembiayaan aktiva perusahaan lebih banyak berasal dari utang dibandingkan dengan modal sendiri.

Menurut Sudana (2011:159) ketika utang yang digunakan melampaui jumlah tertentu, kemampuan perusahaan untuk menghasilkan laba lebih kecil dibandingkan dengan suku bunga yang dibayar oleh perusahaan.

\subsection{Current Ratio}

Menurut Syahyunan

(2013:93),

"current ratio untuk menghitung kemampuan perusahaan dalam membayar kewajiban jangka pendek dengan asset lancar yang tersedia."

Menurut Hery (2015:179), "berdasarkan hasil perhitungan rasio, perusahaan yang memiliki rasio lancar yang kecil mengindikasikan bahwa perusahaan tersebut memiliki modal kerja (aset lancar) yang sedikit untuk membayar kewajiban jangka pendeknya. Dalam praktik, standar rasio lancar yang baik adalah 200\% atau 2:1.

Menurut Horne dan Wachowicz (2014:254) profitabilitas berbanding terbalik dengan likuiditas. Peningkatan likuiditas biasanya dibayar dengan penurunan profitabilitas.

\subsection{Return On Asset}

Menurut Hery (2015:228), Return on asset merupakan rasio yang menunjukkan seberapa besar kontribusi aset dalam menciptakan laba bersih. Dengan kata lain, rasio ini digunakan untuk mengukur seberapa besar jumlah laba bersih yang akan dihasilkan dari setiap rupiah dana yang tertanam dalam total asset".

Menurut Sudana (2011:22), menyatakan bahwa "Return on asset menunjukkan kemampuan perusahaan dagang menggunakan seluruh aktiva yang dimiliki untuk menghasilkan laba setelah pajak. Rasio ini penting bagi pihak manajemen untuk mengevaluasi efektivitas dan efisiensi manajemen perusahaan dalam mengelola seluruh aktiva perusahaan. Semakin besar return on asset, berarti semakin efisien penggunaan aktiva perusahaan atau dengan kata lain dengan jumlah aktiva yang sama bisa dihasilkan laba yang lebih besar dan sebaliknya".

\section{Metode Penelitian}

\subsection{Pendekatan Penelitian}

Pendekatan penelitian yang digunakan adalah penelitian deduktif. Menurut Sujarweni (2014:12), penelitian deduktif adalah penelitian yang mempunyai sifat umum menjadi khusus artinya penelitian ini harus diawali dengan adanya sebuah teori yang sudah ada, kemudian diadakan penelitian untuk membuktikan teori yang sudah ada tersebut.

\subsection{Jenis Penelitian}

Jenis penelitian yang digunakan adalah penelitian kuantitatif. Menurut Sujarweni (2014:6), penelitian kuantitatif adalah jenis penelitian yang menghasilkan penemuanpenemuan yang dapat dicapai dengan menggunakan prosedur-prosedur statistik atau cara-cara lain dari kuantifikasi (pengukuran).

\subsection{Sifat Penelitian}

Sifat penelitian yang digunakan adalah penelitian deskriptif. Menurut Sujarweni (2014:11), penelitian deskriptif adalah penelitian yang dilakukan untuk mengetahui nilai masing-masing variabel, baik satu variabel atau lebih sifatnya independen tanpa membuat hubungan maupun perbandingan dengan variabel yang lain.

\subsection{Populasi dan Sampel}


Populasi yang digunakan dalam penelitian ini adalah semua perusahaan Property dan Real Estate yang terdaftar (listed) di Bursa Efek Indonesia sejak tahun 2014 sampai dengan tahun 2017. Jumlah populasi dalam penelitian ini adalah berjumlah 49 perusahaan.

Teknik pengambilan sampel dalam penelitian ini adalah berdasarkan samplingpurposive. Adapun kriteria-kriteria dalam pemilihan sampel adalah sebagai berikut:

\section{Tabel 1Tabel Pemilihan Sampel}

\begin{tabular}{|c|l|c|}
\hline No & \multicolumn{1}{|c|}{ Keterangan } & Jumlah \\
\hline 1. & $\begin{array}{l}\text { Perusahaan Property dan Real } \\
\text { Estateyang terdaftar di BEI }\end{array}$ & 49 \\
\hline & $\begin{array}{l}\text { Perusahaan Property dan Real } \\
\text { Estate yang tidak publish laporan } \\
\text { keuangan di Bursa Efek Indonesia } \\
\text { tahun 2014-2017 secara berturut- } \\
\text { turut }\end{array}$ & (8) \\
\hline 3. & $\begin{array}{l}\text { Perusahaan Property dan Real } \\
\text { Estateyang rugi selama tahun } \\
\text { 2014-2017 secara berturut-turut }\end{array}$ & $(10)$ \\
\hline & Jumlah sampel penelitian & $\mathbf{3 1}$ \\
\hline
\end{tabular}

Total jumlah sampel yang digunakan dalam penelitian ini yaitu 124 sampel yang diambil dari jumlah sampel 31 perusahaan dikalikan dengan 4 periode penelitian.

\subsection{Teknik Pengumpulan Data}

Metode pengumpulan data dalam penelitian ini dilakukan dengan studi dokumentasi yang merupakan teknik pengumpulan dengan cara mencatat, megumpulkan, dan mempelajari data-data perusahaan terkait masalah yang sedang diteliti mengenai total asset turnover, debt to equity ratio, current ratio dan return on asset setiap sampel dengan bersumber dari laporan keuangan perusahaan Property dan Real Estateyang dipublikasikan oleh Bursa Efek
Indonesia (BEI) sejak tahun 2014 sampai dengan 2017.

\subsection{Jenis dan Sumber Data Penelitian}

Data yang digunakan dalam penelitian ini adalah data sekunder. Data sekunder merupakan data primer yang telah diolah lebih lanjut, misalnya dalambentuk tabel, grafik, diagram, gambar, dan sebagainya sehingga lebih informatif jika digunakan oleh pihak lain. Data sekunder tersebut diperoleh dari situs www.idx.co.id dalam bentuk laporan keuangan perusahaan sampel yang dipublikasikan.

\subsection{Definisi Operasional Variabel Penelitian}

Variabel independen dalam penelitian ini adalah Return on Asset. Menurut Wira (2011:72), menyatakan bahwa“Return on assetadalah rasio yang dihitung dengan membagi laba dengan total aset perusahaan".Menurut Murhadi (2015:64), rumus untuk menghitung return on asset adalah:

$$
\text { ROA }=\frac{\text { Net Income }}{\text { Total Aset }}
$$

Adapun variabel independen dalam penelitian ini yaitu :

1. Total Asset Turnover

Menurut Sartono (2010:120),rumus untuk menghitungtotal asset turnover adalah:

Penjualan

\section{$\mathrm{TATO}=$}

\section{Aktiva}

\section{Debt to Equity Ratio}

Menurut Kasmir (2015:158) rumus untuk menghitung Debt to Equity Ratio adalah:

$$
\text { DER }=\frac{\text { Total Utang }}{\text { Ekuitas (Equity) }}
$$

\section{Current Ratio}

Menurut Gumanti (2011:112) rumus untuk menghitung current ratioadalah: 


\section{Rasio Lancar $=\frac{\text { Aset Lancar }}{\text { Utang Lancar }}$}

\subsection{Kerangka Konseptual}

Adapun kerangka konseptual dalam penelitian ini adalah:

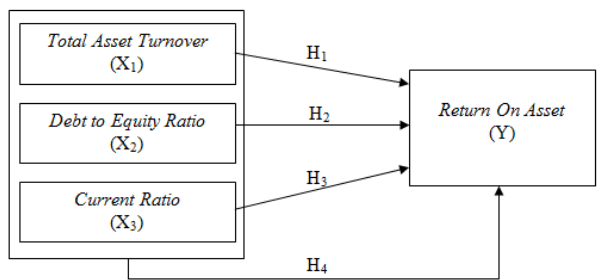

\section{Gambar 1Kerangka Konseptual}

Berdasarkan kerangka konseptual yang telah digambarkan maka hipotesis yang diajukan dalam penelitian ini adalah sebagai berikut:

$\mathrm{H}_{1}$ : Total Asset Turnover berpengaruh secara parsial terhadap Return on Asset pada perusahaan property dan real estate yang tercatat di Bursa Efek Indonesia periode 2014-2017.

$\mathrm{H}_{2}$ : Debt to Equity Ratio berpengaruh secara parsial terhadap Return on Asset

Tabel 2Statistik Deskriptif

Descriptive Statistics

\begin{tabular}{|l|r|r|r|r|r|}
\hline & \multicolumn{1}{|c|}{$\mathrm{N}$} & Minimum & Maximum & \multicolumn{1}{c|}{ Mean } & Std. Deviation \\
\hline TATO & 124 & .012 & .521 & .22054 & .092340 \\
DER & 124 & .068 & 3.701 & .79616 & .518138 \\
CR & 124 & .362 & 8.801 & 2.40363 & 1.689637 \\
ROA & 124 & .000 & .359 & .06780 & .056082 \\
Valid N (listwise) & 124 & & & & \\
\hline
\end{tabular}

Sumber : Hasil Pengolahan Data,2019

VariabelTotal Asset Turn Over memiliki jumlah sampel $(\mathrm{N})$ sebanyak 124, dengan nilai minimum adalah sebesar 0,012 yang diperoleh pada PT. Greenwood Sejahtera, Tbk tahun 2017. Nilai maksimum Total Asset Turn Over adalah sebesar 0,521yang diperoleh pada PT. Fortune Mate Indonesia, Tbk tahun 2014. Nilai rata-rata Total Asset Turn Over property dan real estate periode 2014-2017adalah 0,22054. pada perusahaan property dan real estate yang tercatat di Bursa Efek Indonesia periode 2014-2017.

$\mathrm{H}_{3}$ : Current Ratio berpengaruh secara parsial terhadap Return on Asset perusahaan property dan real estate yang tercatat di Bursa Efek Indonesia periode 2014-2017.

$\mathrm{H}_{4}$ : Total Asset Turnover, Debt to Equity Ratio dan Current Ratio berpengaruh secara simultan terhadap Return on Asset pada perusahaan property dan real estate yang tercatat di Bursa Efek Indonesia periode 2014-2017.

\section{IV.Hasil dan Pembahasan}

\subsection{Statistik Deskriptif}

Sampel yang memenuhi kriteria pada penelitian ini adalah 31 perusahaan property dan real estate periode 2014-2017 sehingga data penelitiannya yang diperoleh berjumlah 124. Hasil pengolahan data sampel dapat dilihat dari statistik deskriptif di bawah ini: 
Variabel Current Ratio memiliki jumlah sampel (N) sebanyak 124, dengan nilai minimum adalah sebesar 0,362 yang diperoleh pada PT. Bumi Citra Permai, Tbk tahun 2014. Nilai maksimum Current Ratio adalah sebesar 8,801 yang diperoleh pada PT. Greenwood Sejahtera, Tbk tahun 2016. Nilai rata-rata Current Ratio property dan real estate periode 2014-2017 adalah 2,40363.

VariabelROAmemiliki jumlah sampel (N) sebanyak 124, dengan nilai minimum adalah sebesar 0,000yang diperoleh pada PT. Gading Development, Tbk tahun 2017. Nilai maksimum ROA adalah sebesar 0,359 yang diperoleh pada PT. Fortune Mate Indonesia, Tbk tahun 2016. Nilai rata-rata Return on AssetProperty dan real estate periode 20142017 adalah $0,06780$.

\subsection{Hasil Uji Asumsi Klasik}

Data pada penelitian ini telah memenuhi syarat uji asumsi klasik yaitu berdistribusi normal, tidak terjadi multikolinearitas, tidak terjadi autokorelasi dan tidak terjadi heteroskedastisitas. Berikut hasil uji asumsi klasik yang terdiri dari uji normalitas, uji multikolinearitas, uji autokorelasi dan uji heteroskedastisitas.

\section{Uji Normalitas}

Uji normalitas bertujuan untuk menguji apakah dalam model regresi, variabel pengganggu atau residual memiliki distribusi normal. Uji yang dilakukan dalam normalitas ini adalah dengan melihat grafik Histogram, P$\mathrm{P}$ Plots dan Kolmogorov-Smirnov.Kalau uji normalitas ini dilanggar maka uji statistik menjadi tidak valid untuk jumlah sampel yang kecil.

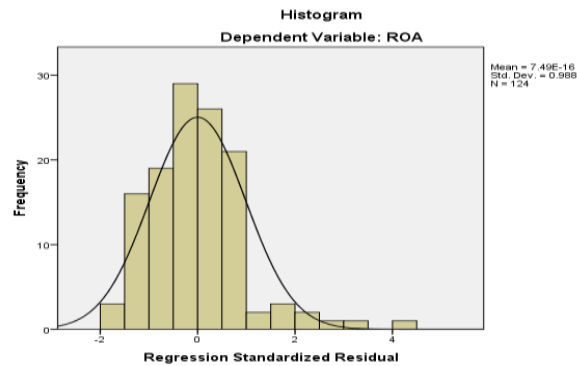

\section{Gambar2Grafik Uji Normalitas Histogram} Sumber : Hasil Pengolahan Data,2019

Grafik histogram pada Gambar 2 di atas menunjukkan garis kurva berbentuk simetri tidak melenceng ke kiri ataupun ke kanan maka dapat dikatakan data telah berdistribusi normal.

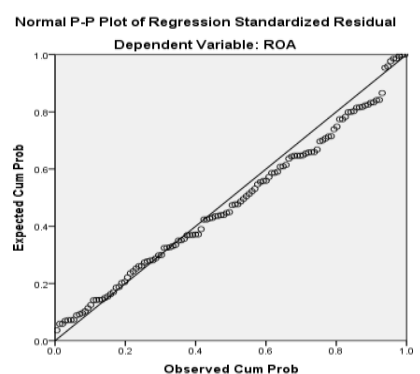

Gambar3 Grafik Uji Normalitas P-P Plot Sumber : Hasil Pengolahan Data,2019

Grafik normalitas P-P Plot pada Gambar 3, terlihat titik-titik mengikuti garis diagonal sehingga dapat dikatakan bahwa model regresi memenuhi asumsi normalitas.

Selain analisis grafik, perlu dilakukan analisis statistik untuk memastikan apakah data benar-benar berdistribusi normal menggunakan uji kolmogorov smirnovtest yang hasil pengujiannya dapat dilihat pada tabel berikut ini :

Tabel3Uji NormalitasKolmogorov Smirnov One-Sample Kolmogorov-Smirnov Test

\begin{tabular}{|ll|r|}
\hline & & \multicolumn{2}{|c|}{$\begin{array}{c}\text { Unstandardized } \\
\text { Residual }\end{array}$} \\
\hline $\mathrm{N}$ & Mean & 124 \\
Normal Parameters & a,b-7 \\
& Std. & 04029338 \\
& Deviation & .083 \\
Most Extreme & Absolute & .083 \\
Differences & Positive & -.048 \\
Kolmogorov-Smirnov Z & Negative & .920 \\
Asymp. Sig. (2-tailed) & & .366 \\
\hline
\end{tabular}


a. Test distribution is Normal.

b. Calculated from data.

\section{Sumber : Hasil Pengolahan Data,2019}

Hasil uji normalitas Kolmogorov Smirnov pada Tabel 4 menunjukkan nilai signifikan sebesar 0,366 dimana lebih besar dari 0,05. Jadi dengan demikian hasil uji normalitas KolmogorovSmirnov disimpulkan data penelitian berdistribusi normal.

\section{Uji Multikolinearitas}

Uji multikolinearitas untuk menguji apakah pada model regresi ditemukan adanya korelasi antar variabel independendapat dilakukan dengan melihat nilai VIF (Variance Inflation Factor) dan Tolerance.

Tabel 4Uji Multikoloniearitas Coefficients $^{\mathrm{a}}$

\begin{tabular}{|rr|r|r|}
\hline \multirow{2}{*}{ Model } & \multicolumn{2}{c|}{ Collinearity Statistics } \\
\cline { 3 - 4 } & & Tolerance & \multicolumn{1}{c|}{ VIF } \\
\hline \multirow{3}{*}{1} & TATO & .902 & 1.109 \\
& DER & .804 & 1.243 \\
& CR & .873 & 1.146 \\
\hline
\end{tabular}

\section{Sumber : Hasil Pengolahan Data,2019}

Hasil uji multikolinearitas pada Tabel 4 menunjukkan nilai toleranceTotal Asset Turn Over sebesar 0,902 > 0,1 dan VIF 1,109 $<$ 10, nilai toleranceDebt to Equity Ratio sebesar $0,804>0,1$ dan VIF $1,243<10$, nilai toleranceCurrent Ratio sebesar 0,873>0,1 dan VIF 1,146 < 10,

Dengan demikian hasil uji Multikolinearitas dapat disimpulkan tidak terjadi regresi antar variabel independen Total Asset Turn Over, Debt to Equity Ratio dan Current Ratio karena semua variabel independen memiliki nilai tolerance diatas 0,1 dan nilai VIF dibawah 10.

\section{Uji Autokorelasi}

Uji ini bertujuan untuk menguji apakah dalam model regresi linier ada korelasi antara kesalahan pengganggu pada periode $t$ dengan periode t-1 (sebelumnya). Untuk mengetahui ada atau tidak nya autokolerasi dalam suatu model penelitian, maka dapat diukur berdasarkan uji Durbin Watson. Hasil penelitian uji autokorelasi dapat dilihat pada tabel berikut:

Tabel 5Uji Autokorelasi Model Summary ${ }^{b}$

\begin{tabular}{l|c|r|r|r|r|}
\hline Model & $\mathrm{R}$ & $\begin{array}{c}\mathrm{R} \\
\text { Square }\end{array}$ & $\begin{array}{c}\text { Adjusted } \\
\text { R Square }\end{array}$ & $\begin{array}{c}\text { Std. Error } \\
\text { of the } \\
\text { Estimate }\end{array}$ & $\begin{array}{l}\text { Durbin- } \\
\text { Watson }\end{array}$ \\
\hline 1 & $.696^{\mathrm{a}}$ & .484 & .471 & .040794 & 2.297 \\
\hline
\end{tabular}

\section{Sumber : Hasil Pengolahan Data,2019}

Hasil uji autokorelasi pada Tabel 6menunjukkan nilai Durbin-Watson sebesar 1,838; besar nilai dl (batas bawah) $=1,6577$ dan du (batas atas) $=1,7567 ; 4-\mathrm{dl}=2,3423$ dan $4-\mathrm{du}=2,2433$. Dengan melihat kriteria pada pedoman Durbin-Watson maka nilai 4-du $\leq \mathrm{d} \leq 4$-dl atau 2,2433 < 2,297 < 2,3423 maka dari hasil uji Autokorelasi tidak dapat diambil kesimpulan terdapat autokorelasi negatif.

Pada penelitian ini untuk menunjukkan data tidak terjadi autokorelasi juga menggunakan uji run test dimana hasil pengujiannya dapat dilihat pada tabel berikut :

\section{Tabel 6Uji Run Test} Runs Test

\begin{tabular}{|l|r|}
\hline & $\begin{array}{r}\text { Unstandardized } \\
\text { Residual }\end{array}$ \\
\hline Test Value & -.00393 \\
Cases < Test Value & 62 \\
Cases >= Test Value & 62 \\
Total Cases & 124 \\
Number of Runs & 64 \\
Z & .180 \\
Asymp. Sig. (2-tailed) & .857 \\
\hline
\end{tabular}

a. Median

\section{Sumber : Hasil Pengolahan Data,2019}

Berdasarkan hasil uji pada tabel 7 diatas dapat dilihat nilai signifikan yang diperoleh sebesar 0,857>0,05 sehingga dapat disimpulkan jika hasil uji run test menunjukkan data penelitian tidak terjadi autokorelasi.

\section{Uji Heteroskedastisitas}

Uji heteroskedastisitas untuk menguji apakah dalam model regresi terjadi ketidaksamaan variancedari residual satu 
pengamatan ke pengamatan yang lain. Berikut uji heteroskedastisitas dapat dilihat dari grafik scatterplot.

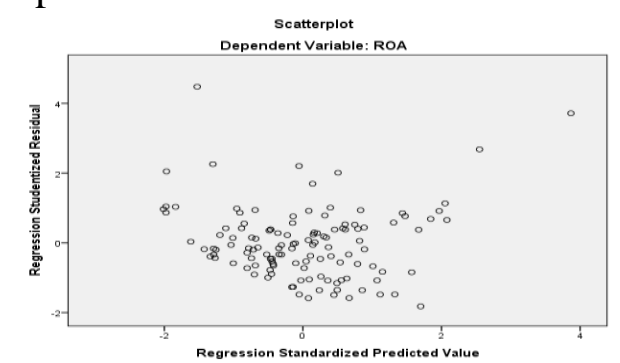

Gambar4 Uji Scatterplot

Sumber : Hasil Pengolahan Data,2019
Dari grafik scatterplot terlihat bahwa titik-titik menyebar secara acak baik diatas maupun dibawah angka nol (0) pada sumbu Y, tidak berkumpul disatu tempat, sehingga dari grafik scatterplotdapat disimpulkan bahwa tidak terjadi heteroskedastisitas pada model regresi.

Pendeteksian ada tidaknya heteroskedastisitas bisa juga dilakukan dengan menggunakan uji Spearman's rho, berikut hasil uji nya :

Tabel 7Uji Spaerman's rho

Correlations

\begin{tabular}{|c|c|c|c|c|c|c|}
\hline & & & TATO & DER & $\mathrm{CR}$ & $\begin{array}{l}\text { Unstandardized } \\
\text { Residual }\end{array}$ \\
\hline \multirow{12}{*}{$\begin{array}{l}\text { Spearman's } \\
\text { rho }\end{array}$} & \multirow{3}{*}{ TATO } & Correlation Coefficient & 1.000 & $.361^{* *}$ & -.062 & -.028 \\
\hline & & Sig. (2-tailed) & & .000 & .495 & .754 \\
\hline & & $\mathrm{N}$ & 124 & 124 & 124 & 124 \\
\hline & \multirow{3}{*}{ DER } & Correlation Coefficient & $.361^{* *}$ & 1.000 & $-.492^{* *}$ & -.016 \\
\hline & & Sig. (2-tailed) & .000 & & .000 & .857 \\
\hline & & $\mathrm{N}$ & 124 & 124 & 124 & 124 \\
\hline & \multirow{3}{*}{ CR } & Correlation Coefficient & -.062 & $-.492^{* *}$ & 1.000 & -.087 \\
\hline & & Sig. (2-tailed) & .495 & .000 & & .337 \\
\hline & & $\mathrm{N}$ & 124 & 124 & 124 & 124 \\
\hline & \multirow{3}{*}{$\begin{array}{l}\text { Unstandardized } \\
\text { Residual }\end{array}$} & Correlation Coefficient & -.028 & -.016 & -.087 & 1.000 \\
\hline & & Sig. (2-tailed) & .754 & .857 & .337 & \\
\hline & & $\mathrm{N}$ & 124 & 124 & 124 & 124 \\
\hline
\end{tabular}

**. Correlation is significant at the 0.01 level (2-tailed).

\section{Sumber : Hasil Pengolahan Data,2019}

Hasil uji Spearman's rho Pada Tabel 8 di atas menunjukkan nilai signifikan dari 3 variabel independen yaitu Total Asset Turn Over 0,754 > 0,05 Debt to Equity Ratio 0,857 > 0,05 dan Current Ratio 0,337 > 0,05 dengan demikian dari hasil uji Glejser dapat disimpulkan tidak terjadi masalah Heteroskedastisitas.

\subsection{Hasil Analisis Data Penelitian Model Penelitian}

Pengujian hipotesis yang digunakan dalam penelitian adalah dengan menggunakan analisis regresi linier berganda. Model regresi yang digunakan adalah sebagai berikut :

Return on Asset $=0,022+0,422$ Total Asset Turn Over - 0,047 Debt to Equity Ratio0,004 Current Ratio

Makna dari persamaan regresi linier berganda di atas adalah :

1. Konstanta sebesar 0,022 satuan menyatakan bahwa jikaTotal Asset Turn Over, Debt to Equity Ratio, dan Current Ratio konstan (tetap) maka Return on Assetsebesar 0,022 satuan. 
2. Koefisien regresi Total Asset Turn Over sebesar 0,422 satuan menyatakan bahwa setiap kenaikan 1 satuan Total Asset Turn Over akan menyebabkan peningkatan Return on Asset sebesar 0,422 satuan.

3. Koefisien regresi Debt to Equity Ratiosebesar - 0,047 satuan menyatakan bahwa setiap kenaikan1 satuanDebt to Equity Ratio akan menyebabkan penurunan Return on Asset sebesar - 0,047 satuan.

4. Koefisien regresi Current Ratio sebesar 0,004 satuan menyatakan bahwa setiap kenaikan1 satuan Current Ratio akan menyebabkan penurunan Return on Asset sebesar - 0,004 satuan.

\section{Koefisien Determinasi Hipotesis}

Koefisien determinasi ditujukan untuk mengetahui seberapa besar kemampuan model dalam menerangkan variabel terikat.

\section{Tabel 8Uji Koefisien Determinasi Model Summary}

\begin{tabular}{|l|r|r|r|r|}
\hline Model & \multicolumn{1}{|c|}{$\mathrm{R}$} & $\mathrm{R}$ Square & $\begin{array}{c}\text { Adjusted R } \\
\text { Square }\end{array}$ & $\begin{array}{r}\text { Std. Error of } \\
\text { the Estimate }\end{array}$ \\
\hline 1 & $.696^{\mathrm{a}}$ & .484 & .471 & .040794 \\
\hline
\end{tabular}

a. Predictors: (Constant), CR, TATO, DER

Sumber : Hasil Pengolahan Data,2019

Berdasarkan Tabel 8 hasil Uji Koefisien Determinasi diperoleh nilai Adjusted $R$ Square sebesar 0,471 hal ini berarti mengindikasi bahwa variasi dari Total Asset Turn Over, Debt to Equity Ratio dan Current Ratio menjelaskan Return on Asset sebesar47,1\% sedangkan sisanya sebesar $52,9 \%$ dipengaruhi oleh variabel lain yang tidak diteliti sepertiinventory turnover, perputaran kas, perputaran piutang, modal kerja dan lainnya.

\section{Pengujian Hipotesis Secara Simultan}

Uji $F$ digunakan untuk menunjukkan apakah semua variabel independen yang dimasukkan dalam model mempunyai pengaruh secara bersama-sama terhadap variabel dependen.

Tabel 9Uji F

ANOVA ${ }^{a}$

\begin{tabular}{|ll|r|r|r|r|r|}
\hline Model & Sum of Squares & df & Mean Square & F & Sig. \\
\hline \multirow{4}{*}{1} & Regression & .187 & 3 & .062 & 37.488 & $.000^{\mathrm{b}}$ \\
& Residual & .200 & 120 & .002 & & \\
& Total & .387 & 123 & & & \\
\hline
\end{tabular}

a. Dependent Variable: ROA

b. Predictors: (Constant), CR, TATO, DER

\section{Sumber : Hasil Pengolahan Data,2019}

Hasil uji Fmenunjukkan $\mathrm{F}$ hitung = 37,488> $\mathrm{F}$ tabel $=2,68$ dengan tingkat signifikansi 0,000. Karena $\mathrm{F}$ hitung $>\mathrm{F}$ tabel dan signifikansi $<0,05$ maka $\mathrm{H}_{\mathrm{a}}$ diterima artinya secara bersama-sama Total Asset Turn Over, Debt to Equity Ratio danCurrent Ratio berpengaruh terhadap Return on Asset pada perusahaanProperty dan real estate yang terdaftar di Bursa Efek Indonesia periode 2014-2017.

\section{Pengujian Hipotesis Secara Parsial}

Pengujian t-test digunakan untuk menunjukkan seberapa jauh pengaruh satu variabel independen terhadap variabel dependen. 
Tabel 11Uji t

Coefficients $^{\mathrm{a}}$

\begin{tabular}{|c|c|c|c|c|c|c|}
\hline \multirow[t]{2}{*}{ Mod } & & \multicolumn{2}{|c|}{ Unstandardized Coefficients } & Standardized & \multirow[t]{2}{*}{$\mathrm{t}$} & \multirow[t]{2}{*}{ Sig. } \\
\hline & & $B$ & Std. Error & Beta & & \\
\hline \multirow{4}{*}{1} & (Constant) & .022 & .013 & & 1.679 & .096 \\
\hline & TATO & .422 & .042 & .695 & 10.066 & .000 \\
\hline & DER & -.047 & .008 & -.430 & -5.881 & .000 \\
\hline & $\mathrm{CR}$ & -.004 & .002 & -.122 & -1.745 & .084 \\
\hline
\end{tabular}

a. Dependent Variable: ROA

Sumber : Hasil Pengolahan Data,2019

Nilai t tabel untuk probabilitas 0,05 pada derajat bebas (df) $=120$ adalah sebesar 1,97993. Dengan demikian berdasarkan Tabel 11 hasil dari Uji t dapat dijelaskan sebagai berikut:

1. Nilai $\mathrm{t}$ hitung $>\mathrm{t}$ tabel atau 10,066>1,97993 dan signifikan $0,000<0,05$ maka $\mathrm{H}_{\mathrm{a}}$ diterima artinya secara parsial Total Asset Turn Over berpengaruh positifdan signifikan terhadap Return on Asset pada perusahaanProperty dan real estate yang terdaftar di Bursa Efek Indonesia periode 2014-2017.

2. Nilai -t hitung < -t tabel atau $5,881<-1,97993$ dan signifikan $0,000<0,05$ maka $\mathrm{H}_{\mathrm{a}}$ diterima artinya secara parsialDebt to Equity Ratioberpengaruh negatifdan signifikan terhadapReturn on Assetpada perusahaanProperty dan real estate yang terdaftar di Bursa Efek Indonesia periode 2014-2017.

3. Nilai -t hitung < - t tabel atau $1,745<-1,97993$ dan signifikan $0,084>0,05$ maka $\mathrm{H}_{0}$ diterima artinya secara parsial Current Ratio tidak berpengaruh terhadap Return on Asset pada perusahaanProperty dan real estate yang terdaftar di Bursa Efek Indonesia periode 2014-2017.

\section{Kesimpulan \\ Pengaruh Total Asset Turn Over TerhadapReturn on Asset}

Berdasarkan hasil pengujian sejalan dengan hipotesis bahwa Total Asset Turn Over berpengaruh positif dansignifikan terhadap Return on Asset pada perusahaan property dan real estate periode 2014-2017.

Hasil penelitian ini sejalan dengan hasil penelitian Pranata, dkk (2014) yang terbukti secara parsial Total Asset Turn Over berpengaruh positif signifikan terhadap Return on Asset.

Hasil penelitian ini sejalan dengan pendapat Sartono (2015:120), perputaran total aktiva, menunjukkan bagaimana efektivitas perusahaan menggunakan keseluruhan aktiva untuk menciptakan penjualan dan mendapatkan laba.

Berdasarkan hasil penelitian ini menunjukkan adanya aset yang dimiliki oleh perusahaan dapat mendukung kegiatan efektivitas perusahaan untuk menghasilkan penjualan. Aset yang dimiliki dapat berupa aset lancar maupun aset tidak lancar. Semakin besar aset yang 
dimiliki perusahaan property dan realestate maka semakin besar kemungkinan perusahaan memperoleh keuntungan.

\section{Pengaruh Debt to Equity Ratio Terhadap Return on Asset}

Berdasarkan hasil pengujian sejalan dengan hipotesis bahwa Debt to Equity Ratio berpengaruh terhadap Return on Asset pada perusahaan property dan real estate periode 20142017.

Hasil penelitian ini sejalan dengan penelitian yang dilakukan oleh Dewi, dkk (2015) yaitu Debt to Equity Ratio berpengaruh negatif dan signifikan terhadap Return on Asset.

Hasil penelitian ini sejalan dengan pendapat Sudana (2011:159) ketika utang yang digunakan melampaui jumlah tertentu, kemampuan perusahaan untuk menghasilkan laba lebih kecil dibandingkan dengan suku bunga yang dibayar oleh perusahaan

Jika perusahaan lebih banyak menggunakan data eksternal maka beban bunga yang akan dibayarkan oleh perusahaan akan semakin besar sehingga hal ini akan menyebabkan penurunan pada profitabilitas. Penggunaan hutang perlu pengamatan secara menyeluruh apakah memberikan manfaat yang lebih besar dari beban yang harus dibayarkan oleh perusahaan atau tidak, hal ini dikarenakan perusahaan property dan real estate dalam kegiatan operasionalnya selalu memerlukan dana yang cukup besar.

\section{PengaruhCurrent RatioTerhadap Return on Asset}

Berdasarkan hasil pengujian tidak sejalan dengan hipotesis bahwa Current Ratio tidak berpengaruh terhadap Return on Asset pada perusahaan property dan real estate periode 2014-2017.

Hasil penelitian ini tidak sejalan dengan penelitian yang dilakukan oleh Wartono (2018), bahwa Current Ratio tidak berpengaruh terhadap Return on Asset.

Hasil penelitian ini tidak sejalan dengan pendapat Horne dan Wachowicz (2014:254) profitabilitas berbanding terbalik dengan likuiditas. Peningkatan likuiditas biasanya dibayar dengan penurunan profitabilitas.

Dengan adanya penelitian ini mengindikasikan bahwa tidak selamanya current ratio yang tinggi biasanya dibayar oleh penurunan profitabilitas. Hal ini dikarenakan jika perusahaan property dan real estate memiliki current ratio yang tinggi dalam memenuhi kewajiban lancarnya kepada pihak lain, maka kegiatan pembangunan real estate akan semakin lancar dan kemungkinan property untuk siap sesuai jadwal semakin besar sehingga perusahaan dapat melakukan pemasaran penjualan property dan real estate.

\section{PENUTUP \\ Kesimpulan}

Kesimpulan dari hasil penelitian ini adalah:

1. Total Asset Turn Over berpengaruh positif dan signifikan terhadap Return on Asset pada perusahaanProperty dan real estate yang terdaftar di Bursa Efek Indonesia periode 2014-2017. 
2. Debt to Equity Ratio berpengaruhnegatif dan signifikan terhadap Return on Asset pada perusahaanProperty dan real estate yang terdaftar di Bursa Efek Indonesia periode 2014-2017.

3. Current Ratio tidak berpengaruh signifikan terhadap Return on Asset pada perusahaanProperty dan real estate yang terdaftar di Bursa Efek Indonesia periode 2014-2017.

4. Total Asset Turn Over, Debt to Equity Ratio, danCurrent Ratio berpengaruh terhadap Return on Asset pada perusahaanProperty dan real estate yang terdaftar di Bursa Efek Indonesia periode 2014-2017.

\section{Saran} adalah:

Saran dari hasil penelitian ini

1. Bagi perusahaan, disarankan untuk mengoptimalkan penggunaan aset untuk menghasilkan keuntungan misalnya melihat peluang investasi yang ada dengan mendirikan mall, kompleks perumahan, perkantoran yang sesuai dengan lokasi, memperhatikan batas aman tingkat penggunaan hutang yang sesuai dengan kebutuhan perusahaan dan memperhatikan kewajiban lancar agar dapat mendukung pembangunan property dan realestate yang sedang berjalan.

2. Bagi peneliti selanjutnya, disarankan untuk menambah variabel lain di luar dari variabel yang diteliti oleh peneliti. Karena hasil uji koefisien menunjukkan 52,9\% dari variasi variabel Return on Asset dipengaruhi oleh variabel lain misalnya inventory turnover, perputaran kas, perputaran piutang, modal kerja dan lainnya.

3. Bagi Universitas Prima Indonesia, disarankan agar dapat mempublikasikan hasil penelitian ini untuk kepentingan penelitian selanjutnya.

4. Bagi investor, disarankan untuk melihat indikator Total Asset Turn Over dan Debt to Equity Ratioapabila ingin mengetahui faktor-faktor yang mempengaruhi Return on Asset pada perusahaan property dan realestate.

\section{DAFTAR RUJUKAN}

Ghozali, Imam. 2016. Aplikasi Analysis Multivariate dengan Program SPSS.Cetakan IV, Semarang: Penerbit BPUniversitas Diponegoro.

Gumanti, Tatang Ary. 2011. Manajemen investasi Konsep, Teori dan Aplikasi. Jakarta: Mitra Wacana Media.

Harahap, Sofyan Safri. 2016. Analisis Kritis atas Laporan Keuangan. Jakarta : PT Raja Grafindo Persada.

Hery. 2015. Analisis Laporan Keuangan Pendekatan Rasio Keuangan. Yogyakarta: Tri Admojo CAPS.

Horne, James C. Van dan John M. Wachowicz. 2016. Prinsip-

Prinsip Manajemen Keuangan . Jakarta : Penerbit Salemba Empat.

Jumingan. 2014. Analisis Laporan Keuangan. Jakarta:PT. Bumi Aksara. 
Jusuf, Jopie. 2016. Analisis Kredit untuk Account Officer. Jakarta: PT. Gramedia Pustaka Utama.

Kasmir. 2015. Analisis Laporan Keuangan.Cetakan ke LimaJakarta: Penerbit PT. RajaGrafindo Persada.

Manullang, M. 2013. Pengantar Bisnis. Jakarta: PT. Indeks

Murhadi, Werner R. 2015. Analisis Laporan Keuangan : Proyeksi dan Valuasi Saham. Jakarta: Penerbit Salemba Empat.

Sanusi, Anwar. 2014. Metodologi Penelitian Bisnis : Disertai Contoh Proposal Penelitian Bidang Ilmu Ekonomi Dan Manajemen. Jakarta: Salemba Empat.

Sartono. 2015. Manajemen Keuangan. Cetakan ke 6, Yogyakarta: BPFEYOGYAKARTA.

Sinaga, Poltak. 2014. Manajemen

Keuangan Teori dan Aplikasi. Medan: CV. Mitra.

Subramanyam, Wild, dkk. 2011. Analisis Laporan Keuangan. Jakarta: Penerbit Salemba Empat.

Sudana, I Made. 2011.Manajemen Keuangan Perusahaan: Teori \& Praktik. Jakarta: Penerbit Erlangga.

Sugiono, Arief dan Edi Untung. 2016.

Panduan Praktis Dasar Analisa Laporan Keuangan. Jakarta: PT. Grasindo.

Sugiyono. 2017. Metode Penelitian Kuantitatif Kualitatif dan $\boldsymbol{R} \& \boldsymbol{D}$. Bandung : PT. Alfabeta. Suwarjeni, V. Wiratna. 2014. Metodologi Penelitian
Lengkap, Praktis dan Mudah Dipahami. Yogyakarta : Pustaka Baru Press.

Syahyunan. 2013. Manajemen Keuangan 1 (Perencanaan, Analisis dan Pengendalian keuangan. Medan: USU Press.

Syaifullah, Hamli. 2014. Buku Praktis Akuntansi Biaya \& Keuangan. Jakarta: Laskar Aksara.

Syamsuddin, Lukman. 2013. Manajemen Keuangan Perusahaan. Edisi Baru. Jakarta: PT.Rajagrafindo Persada.

Wira, Desmond. 2011. Analisis Fundamental Saham. Ed.2, Exceed. 